\title{
REVIEW
}

\section{Disruption of the blood brain barrier is vital property of neurotropic viral infection of the central nervous system}

\author{
M. M. JAMIL AL-OBAIDI ${ }^{1}$, A. BAHADORAN ${ }^{1}$, S. M. WANG ${ }^{2}$, R. MANIKAM ${ }^{3}$, CH. S. RAJU ${ }^{1}$, S. D. SEKARAN
}

${ }^{1}$ Department of Medical Microbiology, Faculty of Medicine, University of Malaya, Kuala Lumpur, Malaysia; ${ }^{2}$ Institute of Medical Molecular Biotechnology, Faculty of Medicine, University Technology Mara, Selangor, Malaysia; ${ }^{3}$ Department of Trauma and Emergency Medicine, University Malaya Medical Centre, Kuala Lumpur, Malaysia; ${ }^{4}$ Department of Microbiology, Faculty of Medicine, MAHSA University, Bandar Saujana Putra, Selangor, Malaysia

Received April 25, 2017; revised July 18, 2017; accepted January 29, 2018

\begin{abstract}
Summary. - The blood brain barrier consisting of astrocytes, pericytes and brain microvascular endothelial cells plays a vital role in the pathogenesis of neurotropic viruses by controlling the access of circulating molecules, immune cells or viruses into the central nervous system (CNS). However, this barrier is not impenetrable and neuroviruses have evolved to disrupt and evade it. This review aims to describe the underlying entry mechanisms of several neuroviruses such as (Japanese encephalitis virus (JEV), West Nile virus (WNV), Zika virus (ZIKV), Nipah virus (NiV), Rabies virus (RABV), Herpes simplex virus (HSV) and Human immunodeficiency virus (HIV)) into the CNS through BBB disruption. The mechanisms, through which neurotropic viruses enter the BBB, are being studied and are becoming clearer, however, some aspects still remain unknown. Some of these viruses are able to invade the brain parenchyma by a 'Trojan horse' mechanism, through diapedesis of infected immune cells that either cross the BBB paracellularly or transcellularly. Important mechanisms of BBB disruption associated with paracellular entry of viruses include alterations in expression or phosphorylation of tight junction proteins, disruption of the basal lamina and disruption of the actin cytoskeleton. In the absence of such mechanisms, indirect effects of viruses on the immune system are likely causes of barrier disruption.
\end{abstract}

Keywords: adhesion molecules; blood-brain barrier; central nervous system; neuroviruses; tight junction

\section{Contents:}

1. Introduction

2. Interaction between virus and CNS immune system

3. The main entry receptor of neurotropic viruses into CNS

4. Blood-brain barrier and its components

5. Neuroviruses and BBB disruption
5.1 Disruption of tight junctions via ICAM-1 and CINC-1

5.2 Uncontrolled entry of immune cells via Trojan horse mechanism

5.3 BBB disruption via direct infection

5.4 Transendothelial permeability leading to compromised $\mathrm{BBB}$

*Corresponding author. E-mail: shamaladevi@mahsa.edu.my, shamalamy@yahoo.com; phone: +60379675759.

Abbreviations: $\mathrm{AM}=$ adhesion molecule; $\mathrm{AIDS}=$ Acquired immune deficiency syndrome; $\mathrm{BBB}=$ blood-brain barrier, $\mathrm{BMECs}=$ brain microvascular endothelial cells; CAMS = endothelial cell adhesion molecules; CINC-1 = cytokine-induced neutrophil chemoattractant 1; CLEC5A=C-type lectin superfamily member $5 ; \mathrm{CNS}=$ central nervous system; $\mathrm{CSF}=$ cerebrospinal fluid; $\mathrm{HSE}=$ Herpes simplex encephalitis; HIV = Human immunodeficiency virus; ICAM-1 = intercellular cell adhesion molecule 1; IFNAR $=$ IFN- $\alpha$ receptor; IRF-3 = IFN regulatory factor 3; JAM $=$ junctional adhesion molecules; JEV = Japanese encephalitis virus; $\mathrm{MCP}=$ methyl-accepting chemotaxis protein; MDA5 = melanoma differentiation-associated protein $5 ; \mathrm{MMPS}=$ multiple matrix metalloproteinases; $\mathrm{NF}-\mathrm{\kappa B}=$ nuclear factor kappa-light-chain-enhancer of activated $\mathrm{b}$ cells; $\mathrm{NiV}=\mathrm{Nipah}$ virus; RABV = Rabies virus; RIG-I = retinoic acid-inducible gene; TJ = tight junctions; TLR = Toll-like receptor; TEER = trans epithelial electrical resistance; VCAM-1 = vascular endothelial cell adhesion molecule 1; WNV = West Nile virus; ZO = zonula occludens; ZIKV = Zika virus 
5.5 Reduction in expression of tight junction proteins and penetration of inflammatory cells

5.6 Degrading MMPs cause BBB disruption via capillary congestion

5.7 Enhancing permeability via alterations in tight junctions and increasing MMP expression

6. Conclusion

\section{Introduction}

Most zoonotic virus infections are highly virulent and neuroinvasive in non-natural hosts. Viral infections are usually initiated at the periphery, mostly at epithelial or endothelial cell surfaces. Upon viral infection, the tissue-specific antiviral responses, such as intrinsic immune responses and paracrine signaling, are initiated from the infected cell to surrounding uninfected cells by secreted cytokines. Additionally, the infection might be cleared by the action of virus-specific antibodies and $\mathrm{T}$ cells of the adaptive immune response. Nevertheless, viral infections may spread to other tissues if the virus escapes from the immune system at the site of primary infection, causing increased virus replication or overreactive innate immune responses. Subsequently, pro-inflammatory and antiinflammatory cytokines are further enhanced in the serum, leading to vigorous systemic immune responses. This reaction can cause devastating effects in the brain resulting in meningitis, encephalitis, meningoencephalitis, or even death. Once the brain is infected with zoonotic viruses, viral clearance by the immune system is a major challenge. Particularly, CNS neurons are irreplaceable and established T-cell-mediated cytolysis of these infected cells is not a favorable strategy. Brain homeostasis is sustained by the structure and function of the blood-brain barrier (BBB). BBB plays a key role in the pathogenesis of neurotropic viruses by controlling the access of circulating molecules, immune cells, or viruses into the central nervous system (CNS). Infectious virus particles, immune cells, inflammatory mediators, and eventual neuronal dysfunction is the main feature of neurotropic virus-related neuropathy in the parenchymal tissues of the CNS. Therefore, this review aims to describe the underlying entry mechanisms of several neuroviruses (JEV, WNV, ZIKV, NiV, RABV, HSV and HIV) into CNS through BBB disruption. A profound understanding of the pathogenesis of these viruses is imperative for the development of effective therapeutic strategies.

\section{Interaction between viruses and CNS immune system}

The innate immune system is a network of pattern recognition receptors (PRRs) (Toll-like receptors (TLR), nucleotide oligomerization domain (NOD)-like receptors (NLRs), retinoic acid inducible gene (RIG)-I-like receptors (RLRs) and DNA sensors) that can identify conserved pathogenaccompanied molecular patterns (PAMPS) on microbes. PRR triggers signaling cascades that encourage nuclear translocation of latent transcription factors (e.g. IFN regulatory factor 3 (IRF-3) and nuclear factor kappa-light-chain-enhancer of activated $\mathrm{B}$ cells $(\mathrm{NF}-\kappa \mathrm{B})$ and induce transcriptional activation of genes that direct and mediate cell immunity against viruses, including secretion of antiviral cytokines (IFN- $\alpha$ and IFN- $\beta$ ). Specific innate immune signaling and effector pathways have been found to confine or contribute to the pathogenesis of different viruses in the CNS. For example, TLR signaling has defensive or pathogenic effects in the CNS. It was demonstrated that TLR3 and TLR7 signaling restricted WNV infection in neurons (Daffis et al., 2008; Town et al., 2009), whereas other studies showed that TLR3 and TLR7 enhanced BBB permeability and viral neuroinvasion after WNV infection (Wang et al., 2004; Welte et al., 2009). In $\mathrm{RABV}$, it was revealed that mice lacking TLR3 had a lower viral load and hence enhanced survival rate following infection, suggesting that TLR3 contributes to pathogenesis. Conversely, TLR3 signaling pathway was shown to have protective effects against encephalitic herpesviruses in humans with primary immunodeficiencies (Nair and Diamond, 2015). Furthermore, it was demonstrated that ZIKV can activate TLR3 in neural progenitor cells (NPCs), thereby resulting in activation of pro-apoptotic pathway or dysregulation of cell integrity (Dang et al., 2016). The second type of recognition receptor in the CNS innate immune system upon viral infection are the RIG-I-like receptors (RLRs), which are able to generate antiviral responses during several neurotropic RNA viruses engagement. RLR signaling preferentially mediates type I IFN production in response to RABV, as mice deficient in the downstream adaptor molecule mitochondrial antiviral signaling protein (MAVS) had improvement in limb paralysis upon infection (Faul et al., 2010). In addition, RLR signaling also restricted WNV replication in the spinal cord and brain, mainly in neurons (Fredericksen et al., 2008). The third type of recognition receptors in CNS innate immune system are DNA sensors. They also have antiviral effects during neurotropic viral infections. For instance, cGAMP synthase (cGAS), a cytoplasmic viral DNA sensor, signals via an adaptor molecule that can stimulate IFN genes (STING). STING recruits threonine-protein kinase 1 (TBK1), leading to the activation of IRF-3, induction of type I IFN and proinflammatory cytokines. A study showed that STINGdeficient mice suffered higher HSV-1 infection in the brain and greater mortality (Ishikawa et al., 2009). Similarly, mice lacking cGAS were more susceptible to HSV-1 and failed to produce type I IFN (Li et al., 2013).

Type I and type III interferons are cytokines that are critical to control early steps of viral infections. The type III IFN family comprises of three subtypes, IFN- $\lambda 1$, IFN- $\lambda 2$ and IFN- $\lambda 3$. The signaling pathway of type III IFNs happens 
through a receptor distinct from that of type I IFNs but the same signal transduction pathway is induced. Nevertheless, the types of cells that respond to type I and type III IFNs are different. Type I IFN receptor can be found on most cell types, but the type III IFN receptor is preferentially expressed by epithelial cells. In the CNS, the expression of type III IFNs is lower than that of type I IFNs in response to viral infections. Different types of cells of the CNS were reported to respond to IFN produced upon viral infection including astrocytes, oligodendrocytes and neurons. However, the specific reaction of CNS cells to IFN- $\lambda$ is very low. An overall weak expression of the IL28R- $\alpha$ subunit of the IFN- $\lambda$ receptor has been shown in the CNS as compared to other tissues. In vivo expression of IFN- $\lambda 3$ was used to identify the cells that can respond to circulating IFN produced by muscle cells in the periphery. In this experiment, the Mxl protein, used as a marker of the IFN response, was detected only in the epithelial cells of choroid plexus and in few meningeal cells. These data are consistent with the epithelial specificity of the IFN- $\lambda$ response. It was also recently observed that IFN- $\lambda$ can inhibit HSV-1 infection in primary human astrocytes (Sorgeloos et al., 2013). However, type I IFNs are the main element of the innate immune response, which perform antiviral activity within both infected and neighboring cells (Sorgeloos et al., 2013). Upon viral entry, the IFN response is triggered, and released/synthesized viral components, such as double-stranded RNA intermediates, that trigger transcription factors such as IRF-3, IRF-7, NF- $\kappa$ B and activating transcription factor 2 (ATF2/c-Jun). Subsequently, IFN- $\alpha / \beta$ is transcribed (Fitzgerald et al., 2003). The release of IFN$\alpha / \beta$ results in binding to the IFN- $\alpha$ receptor (IFNAR) on the surface of infected and nearby cells, leading to the activation of Janus kinase (JAK) / signal transducer and activator of transcription (STAT) pathway. One study showed that IFN$\alpha / \beta$ protects animal hosts against viral infections in mice deficient in the IFN pathway (Durbin et al., 1996). Another study suggests that IFN- $\alpha / \beta$ controls WNV infection by restricting tropism and viral burden by preventing the death of infected neurons (Suthar et al., 2013). It was also shown that induced endogenous IFN could control RABV infection (Marcovistz et al., 1987) and suppress HIV-1 replication in in vivo and in vitro studies (Poli et al., 1989). However, several viruses encode proteins neutralizing the innate immune system by targeting different parts of the IFN production and signaling pathways, leading to the evasion of the IFN-induced antiviral state of the host cell (Fontana et al., 2008; Goodbourn and Randall, 2009). On the other hand, if the innate immune system fails to confine the virus, the adaptive immune system will be activated as it is slow, systemic, and pathogen-specific, leading to stimulation of the immunological memory. The adaptive immune response includes cell-mediated immunity and humoral immunity and involves the action of CD4+ T helper cells, CD8+ cytotoxic T cells (CTLs) and B cells. The humoral immune system produces antibodies against different pathogens. Activated of virus-specific CD4+ helper T cells, both Th1 and Th2 type, recognize virus-derived MHC class II-associated peptides on antigen-presenting cells, followed by expression of co-stimulatory molecules. Activation of CTLs leads to their migration to the infection site, where they detect virus-infected cells and eliminate them via lytic activity or apoptosis induction and hence inhibit the virus progeny production. Predominantly, nervous system tissues depend on the intrinsic and innate immune responses and avoid the extensive inflammation and cytotoxic effects of the adaptive immune response due to their mostly irreplaceable nature (Koyuncu et al., 2013).

\section{The main entry receptor of neurotropic viruses into CNS}

Immune receptors usually exist on cell membranes and they bind to factors like cytokines, resulting in a response of the immune system. Several immune receptors have been identified to limit or contribute to the pathogenesis after viral infection. For example, after JEV infection, macrophages are the main cells in the brain, where on these cells, lactin receptors interact with virus playing an important role in JEV-induced lethality. Previous research reported that JEV interacts with CLEC5A and induces DAP12 phosphorylation in macrophages (Chen et al., 2012). This CLEC5A activation is accompanied by proinflammatory cytokines secretion such as TNF- $\alpha$ and IL- $1 \alpha$. In WNV recognition, TLR3 is considered as a main receptor that can induce IFN responses to protect the CNS from WNV infection, where previous research confirmed that mice deficient for TLR3 and TLR7 showed viral replication enhancement in the CNS after WNV infection (Szretter et al., 2010; Lazear et al., 2011). In ZIKV infections, AXL is an attachment molecule receptor for this virus (Hamel et al., 2015), where it is stimulated in neural stem cells, microglia, radial glial cells and astrocytes (Nowakowski et al., 2016). Recent ex vivo studies demonstrated that AXL receptor was decreased in human astrocytes infected with ZIKV (Retallack et al., 2016; Xu et al., 2016). Additionally, ZIKV-infected primary human skin fibroblast can induce TLR3, RIG-1 and melanoma differentiationassociated protein 5 (MDA5) activation (Hamel et al., 2015). This activation is accompanied by an increase in type 1 IFN production. TLR3 was also activated in cerebral organoids and human neurospheres after neural stem cells were infected with African strain of ZIKV (MR-766) as detected by RT-qPCR (Dang et al., 2016). Induction of transcription of TLR3, RIG-1 and MDA5 by Zika virus infection is observed as well as that of several IFN-stimulated genes such as OAS2, ISG15, and MX1. Increased gene expression of IFN- $\alpha$ and IFN- $\beta$ and IFN-stimulated genes, cytokines, and other im- 
mune modulators such as CCL5, CXCL10, AIM2, and IL-1 $\beta$ was also observed (Nayak et al., 2016). Ephrin B2 (EB2), the main entry receptor of $\mathrm{NiV}$ (Bonaparte et al., 2005; Negrete et al., 2005), is a transmembrane protein that is greatly preserved among all mammalian species. EB2 is a ligand of EphB4 receptor and is involved in angiogenesis and neurogenesis (Poliakov et al., 2004). Although EB2 is basically activated in arteries, different organs can also express EB2. In addition to EB2, EB3 is considered as an alternative receptor for $\mathrm{NiV}$, since EB3 is expressed in the CNS (Negrete et al., 2006). In vivo research showed that EB3 is expressed also on endothelial cells (Argyris et al., 2007). This revealed that EB3 is expressed in brain parenchyma and might therefore be used in some cell types as an alternative receptor in the absence of EB2. EB2 and EB3 are a large family of tyrosine kinase receptors expressed by neurons and brain endothelium (Lee, 2007; Maisner et al., 2009). Interestingly, neural cell adhesion molecule (NCAM) (Thoulouze et al., 1998), p75 nerve growth factor receptor (p75NTR) (Tuffereau et al., 1998) and nicotinic acetylcholine receptor (nAchR) (Lentz et al., 1982) are cellular membrane components that may act as receptors for RABV glycoprotein $\mathrm{G}$, which is responsible for the neurotropism of RABV (Schnell et al., 2010). Once RABV binds to these receptors through viral glycoprotein $G$, a neutralizing antibody response is induced (Wiktor et al., 1973). After internalization, glycoprotein $G$ mediates fusion of the viral envelope with the endosomal membrane (Gaudin et al., 1992). However, these studies need more research to fully understand the mechanisms used by this virus to enter the cell, multiply, replicate and cause disease. TLR2 and TLR9 act synergistically in response to HSV infection in the brain parenchyma (Sørensen et al., 2008). It was shown that HSV burdens the brain at a much higher rate in TLR2 and 9 double knockouts as compared with the brains of single knockouts (Sørensen et al., 2008). Furthermore, TNF- $\alpha$ and CXCL9 expression after HSV infection were dependent on TLR2 and TLR9. Therefore, in terms of an effective immune response to HSV, TLR2 and TLR9 are required mainly in the brain (Sørensen et al., 2008) and provide resistance against HSV infection in the brain. TLR7, 8 and 9 can also confer protective immunity against herpes simplex encephalitis (HSE) in humans (Casrouge et al., 2006). Hence, either suppression or activation of these receptors might be helpful to reduce the pathogenesis of the virus and can provide new insights into the treatment of the severe inflammatory consequences of infection.

\section{Blood-brain barrier and its components}

The blood-brain barrier (BBB) acts as physical and physiological barrier that acts as a selective diffusion barrier, making it a promising neurovascular filtering system that protects the brain from any toxic molecules and infectious agents. It is comprised of the cerebral microvascular endothelium together with pericytes and astrocytes (Abbott et al., 2010). Neurons and microglia are other cellular elements that play an important role in the BBB function (Wilhelm et al., 2011). The BBB is composed of specialized brain microvascular endothelial cells (BMECs) and regulates the flow of molecules and factors into and out of the brain. The passive diffusion of molecules into the brain is limited by complex intercellular tight junctions (TJ); their presence results in extremely high trans-endothelial electrical resistance (TEER). Additionally, returning small lipophilic molecules capable of diffusing from BMECs back to the bloodstream are carried out using efflux transporters such as p-glycoprotein, which contribute to the barrier properties. As a result, BMECs are provided with a necessary network of specific transport systems to transport essential metabolites and nutrients across the BBB. Substantial barrier properties of BBB prevent neuropharmaceutical development by avoiding uptake of the majority of small-molecule pharmaceuticals and essentially all biologics. Conversely, BBB dysfunction and breakdown is associated with a variety of neurological diseases such as multiple sclerosis, Alzheimer's disease, stroke and brain tumors. These issues together have led researchers to develop a variety of $\mathrm{BBB}$ models to enable detailed mechanistic studies and drug screens in vitro. BMECs are the most vital cell type of the $\mathrm{BBB}$ involved in permeability that cover the inner surface of the capillaries, where they are connected by TJs, which form belt-like structures at the apical region of these cells (Wilhelm et al., 2011). While the pericytes cover approximately $22-32 \%$ of the endothelium immersed in the basal membrane, their main role is to regulate endothelial cell proliferation, angiogenesis, and inflammatory processes (Dore, 2008). In their absence, abnormal vasculogenesis, endothelial hyperplasia and increased permeability in the brain were observed (Armulik et al., 2010). The third element of BBB is the astrocytes endfeet (Kacem et al., 1998), which are considered as the main sources of regulatory factors such as transforming growth factor (TGF- $\beta$ ), glial cell-derived neurotrophic factor (GDNF), basic fibroblast growth factor (bFGF) and IL-6 (Pekny et al., 1998).

Several viruses have been known to cause disruption of the $\mathrm{BBB}$ or endothelial junctions. It is believed that numerous viruses enter the brain parenchyma via diapedesis of infected immune cells such as the "Trojan horse" mechanism (Ivey et al., 2009; Verma et al., 2009; Fletcher et al., 2011). Other viruses can enhance the BBB permeability through TJ complex disruption, where they stimulate the production of inflammatory chemokines or cytokines such as IFN- $\alpha$, IL-8, TNF- $\alpha$, and IL- 6 , hence indirectly contributing to BBB breakdown (Lopez et al., 2012); or they infect endothelial cells and release pro-inflammatory mediators enabling the access of the virus into the CNS (McGavern and Kang, 2011). 
The presence of a continuous line of TJs at the cellcell border is one of the most important elements of the BBB phenotype in cerebral endothelial cells (CECs). The molecular components of the TJs can be divided into transmembrane and cytoplasmic plaque proteins. Transmembrane proteins include junctional adhesion molecules (JAMs) (Martìn et al., 1998), occludin (Furuse et al., 1993) and members of the claudin family (Furuse et al., 1998). These network of proteins and molecules control the passage of the compounds into and out of the brain (Lehner et al., 2011; Mariano et al., 2011). Occludin plays an important role in the formation of the TJ complex (Luissint et al., 2012). Claudins form the TJ backbone and preserve the integrity of the BBB. Brain endothelial cells express claudin-5 (Morita et al., 1999) and to a smaller extent claudin-3, -10, -12 (Ohtsuki et al., 2008) in normal conditions. The second type of proteins (cytoplasmic plaque) act as an intermediary between transmembrane proteins and actin cytoskeleton, such as PDZ-containing proteins, non-PDZ proteins (e.g. cingulin) (Citi et al., 1988; Citi et al., 1989), zonula occludens (ZO)-1 (Stevenson et al., 1986), ZO-2 (Gumbiner et al., 1991) and junction-associated coiled-coil protein/paracingulin (JACOP) (Ohnishi et al., 2004). In addition, cell adhesion molecules (CAMs) are cell surface molecules that enable intercellular binding and communication (Kobayashi et al., 2007). During viral infections, CAMs are responsible for recruiting leukocytes into the vascular endothelium before extravasating into the injured tissues. Vascular endothelial cell adhesion molecule 1 (VCAM-1), intercellular cell adhesion molecule 1 (ICAM-1), and platelet endothelial cell adhesion molecule 1 (PECAM-1) are examples of CAMs. Under healthy circumstances, the endothelial cells of the BBB express very low levels of CAMs.

\section{Neuroviruses and BBB disruption}

As mentioned earlier, zoonotic infections are the most devastating causes of viral encephalitis caused by pathogens (Koyuncu et al., 2013). It has been documented that a large number of infected subjects will develop encephalitis and other neurological consequences after viral infection (Tyler, 2009). The virus may replicate in neurons and glia after crossing the BBB to infect CNS (Hauwel et al., 2005; Savarin and Bergmann, 2008). Eventually, any CNS virus infection shows a balance between the beneficial effects of the brains' protective innate immune response and detrimental effects of bystander injury due to the consequences of ineffective clearance of the virus by infiltrating systemic NK and T cells. If the balance favors the latter, determined brain inflammation will be the result with either an acute or chronic encephalitis (Schnell et al., 2010).

\subsection{Disruption of tight junctions via ICAM-1 and CINC-1}

Acute encephalopathy is one of the phenomena of flaviviruses infection such as JEV, WNV and ZIKV, where the envelope (E) protein glycosylation has the main role as virulence determinant (Shirato et al., 2004). Pathologically, the neuroinflammation observed in Japanese encephalitis (JE) infections in the CNS is due to BBB disruption stimulated by JEV (Diagana et al., 2007). Several reports have revealed that the disruption of the $\mathrm{BBB}$ and signs of endothelial damage are concurrent with the presence of viral particles in $\mathrm{BBB}$ endothelial cells in a JE mouse model (German et al., 2006; Mishra et al., 2009). Recent findings showed that JEV-infected endothelial cells can express extra ICAM-1 and cytokine-induced neutrophil chemoattractant 1 (CINC-1) participating in some steps of leukocyte trafficking into the CNS (Lai et al., 2012). This mechanism attracts immune cells into the brain and finally leads to BBB disruption (Zhang et al., 1995). Furthermore, cells expressing JEV significantly compromised permeability barrier by altering the expression of claudin-1, suggesting JEV may play a role in the disruption of TJ functions (Agrawal et al., 2013). A recent study revealed that the BBB integrity was compromised in brain mouse model infected with JEV by reduced TJ genes (claudin-1, claudin- 5 , and ZO-1 occludin,) expression and enhanced AMs expression such as ICAM1 and JAM (Chen et al., 2012). In addition, JEV also induces microglial activation in the brain (Ghoshal et al., 2007), leading to expression of numerous immune-related proteins such as chemokines methyl-accepting chemotaxis protein (MCP-1), macrophage inflammatory protein 1 (MIP$1 \alpha$, MIP-1 $\beta$ ), RANTES), cytokines (IL-1, IL-6, IL-18, TNF- $\alpha$ ), vascular endothelial growth factor (VEGF), lymphotoxin, and multiple matrix metalloproteinases (MMPs) (Banati et al., 1993; Shima et al., 1995; Ubogu et al., 2006). It has been confirmed that high levels of IL- 6 and MCP-1 after virus infection led to increased vascular permeability (Lander et al., 2014). Moreover, deformation of TJs and disruption of the BBB due to high levels of IL-6 have been detected in a mouse model of JE (Gupta and Rao, 2011; Yang et al., 2011).

\subsection{Uncontrolled entry of immune cells via Trojan horse} mechanism

West Nile virus (WNV) is a mosquito-borne enveloped flavivirus that causes encephalitis and meningitis in a small percentage of infected humans after the initial replication in keratinocytes and Langerhans cells in the skin (Lim et al., 2011). WNV can access the CNS either by infecting sensory nerve endings, olfactory neurons or through blood circulation (Lim et al., 2011). The hallmark of WNV neuropathogenesis is the disruption of the BBB resulting in uncontrolled entry of immune cells into the brain via "Trojan horse" mechanism (Wang et al., 2008b), where the leukocyte traffic across the 
BBB in a harmonized process, including tethering, rolling, adhesion and transmigration, that is directed by the interactions of CAMs with their ligands, MMPs and chemokines (Stanimirovic and Satoh, 2000; Dietrich, 2002). A previous study demonstrated that $\mathrm{BBB}$ disruption in WNV-infected mice was accompanied with increased MMPs and loss of TJ proteins (Wang et al., 2008a; Xu et al., 2012), leading to the entry of the virus into the brain. It was also revealed that WNV-infected astrocytes induced TJ proteins degradation associated with loss of TEER and barrier integrity (Verma et al., 2010). Moreover, high levels of pro-inflammatory cytokines and chemokines resulted in the entry of the virus into the brain after WNV infection (Kumar et al., 2010). These studies confirm that WNV has an effect on BBB function and may result in encephalitis and meningitis.

\subsection{BBB disruption via direct infection}

The pathological properties of ZIKV were discussed by Dick (1952). Analysis of ZIKV-infected brains of mice following intraperitoneal infection showed an increase of viral titers over the course of several days, suggesting the virus may cross the blood brain barrier. Other findings conducted by Bell et al. (1971) observed that ZIKV indirectly infected CNS in mice via both glial cells and neurons, creating a variety of intracytoplasmic inclusions or virus factories. There is a strong evidence showing a correlation between ZIKV and microcephaly, where ZIKV was isolated from microcephalic brains of three aborted fetuses and two newborns from mothers with a suspected Zika virus infection. In addition, mothers of microcephalic fetuses/ infants demonstrated the presence of ZIKV between 6 and 13 weeks of gestation (Brasil et al., 2016; Martines, 2016; MeaneyDelman, 2016; Mlakar et al., 2016). Viral antigen was localized to the placenta, microglia, and neurons (Bayer et al., 2016). Recent studies have demonstrated that type I IFNAR-deficient mice crossed with wild-type C57BL/6 mice and C57BL/6 mice treated with blocking anti-IFNAR antibody showed transplacental transmission of ZIKV and some signs of microcephaly (Miner et al., 2016). Another study had also demonstrated that adult IFNAR-deficient mice and other mouse strains lacking one or more components of the type I IFN system are prone to numerous ZIKV strains with high viral loads in the CNS and testis (Lazear et al., 2016; Rossi et al., 2016). Similar to other flaviviruses, we can speculate that a possible mechanism of ZIKV entry into the brain is via BBB disruption. However, further investigations are needed to understand the exact effects of this virus on BBB disruption.

\subsection{Transendothelial permeability leading to compro-} mised $B B B$

A different mechanism of BBB disruption is described for Nipah virus (NiV), where this virus can enter the CNS through the hematogenous route as detected in vasculitis patients (Wong et al., 2002). It has been shown that NiV infects neurons and may spread through the cribriform plate and enter into the olfactory bulb as a mode of entry into the CNS (Munster et al., 2012). In humans, the virus disease is categorized by respiratory distress and encephalitis, with histopathologic changes in the lung and brain showing multinucleated giant cells in the microvasculature (Luby and Gurley, 2012). Approximately $19 \%$ of patients that survive the $\mathrm{NiV}$ infection still suffer from long-term neurological deficit that continues for more than four months after the initial outbreak (Sejvar et al., 2007). However, some patients showed late-onset of encephalitis that occurred up to many years after the initial infection (Abdullah et al., 2012). Endothelial cells are the major target cells during the systemic phase of $\mathrm{NiV}$ infection, which is characterized by a systemic vasculitis, discrete inflammation in most organs and parenchymal necrosis mainly in the CNS. Vasculitis of the small arterioles, arteries, capillaries and venules of the CNS in patients with $\mathrm{NiV}$ encephalitis was detected in autopsies (Wong et al., 2002). NiV-induced endothelial damage observed in cultured peripheral blood mononuclear endothelial cells (PBMECs) is confirmed by an increase in the transendothelial permeability late in infection, leading to compromised BBB as well as penetration of leukocytes in small brain vessels during in vivo infection (Weingartl et al., 2005). Neurological signs of the disease with BBB disruption were also shown in hamsters infected with NiV (De Wit et al., 2011). Thus, the pathogenesis of NiV infection mostly appears to be due to the endothelial destruction, multinucleated syncytia, vasculitis-induced thrombosis, ischemia and microinfarction in the CNS, followed by the infection of neurons and glial cells in the brain parenchyma, allowing the virus to overcome the BBB (Chua et al., 2000; Wong et al., 2002).

5.5 Reduction in expression of tight junction proteins and penetration of inflammatory cells

Similar to JEV mentioned earlier, Rabies virus (RABV) can also induce a deadly neurological disease and have a devastating influence globally. There are two types of RABV: i) laboratory-attenuated RABV and ii) wild-type (wt) RABV. Numerous studies have revealed that the laboratoryattenuated RABV can be cleared from the CNS, due to its ability to induce innate and adaptive immunities such as the production of chemokines, cytokines, and activation of immune cells and its ability to permeate the BBB (Chai et al., 2015). A previous study demonstrated extensive inflammation, apoptosis, and expression of innate immune genes in the CNS of mice infected with laboratory-attenuated RABV (Jackson et al., 2008; Zhao et al., 2009), whereas wt RABV stimulates little or no inflammatory responses (Chai et al., 
2014). Within the peripheral nervous system and CNS, axonal transport process mediates the spread of RABV in a microtubule network-dependent process (Ceccaldi et al., 1989). This process allows RABV to infect and disseminate to all brain neuronal subtypes and spreads to peripheral glands such as salivary, adrenal and lacrymal gland (Charlton, 1988; Fields et al., 2007). The mechanism, by which RABV infection initiates $\mathrm{BBB}$ permeability enhancement in mice has been described by Chai et al. (2015), where it was observed that RABV infection enhances $\mathrm{BBB}$ permeability by reducing the TJ protein expression and inducing penetration of inflammatory cells into the CNS. The enhancement of BBB permeability and the reduction of TJ protein expression is associated with the expression of chemokines/cytokines. Enhancement of BBB permeability is vital in RABV attenuation by allowing immune effectors to access the CNS to clear RABV (Kuang et al., 2009). According to Phares et al. (2006), increased BBB permeability and inflammation occur differently in various parts of the brain, are accompanied by clearance of the virus and a lack of the neurological sequelae in RABV infections of mice.

\subsection{Degrading MMPs cause BBB disruption via capillary congestion}

HSV is another neurotropic virus that can induce HSE. It is one of the ultimate devastating infectious diseases of the CNS with the mortality of up to $20 \%$ and neurological sequelae in over $50 \%$ of the survivors (Raschilas et al., 2002). The olfactory and trigeminal nerves were suggested as potential pathways of this virus to the CNS (Johnson et al., 1968; Schlitt et al., 1986). Interestingly, former studies have indicated that brains of elderly Alzheimer's patients have shown the presence of HSV-1 within the brain regions affected by Alzheimer's disease (Jamieson et al., 1991). Hudson et al. (1991) stated that the intranasal inoculation of HSV-1 in mice produces focal lesions localized to the temporal lobe, similar to what is observed in humans. A more recent study showed that parenchymal injury is mediated by direct lytic effects of the HSV on neurons and glial cells, resulting in inflammatory reaction and finally collateral damage (Sellner et al., 2005). It was shown that early signs in the course of the disease comprise vascular alterations with disruption of the $\mathrm{BBB}$, congestion of capillaries and petechiae in experimental models of HSV and human cases (Arsenio et al., 1975; Farkas et al., 1975). Degrading MMPs are believed to play a main role in stimulating BBB disruption in CNS infections (Lo et al., 2002). In a mouse model of HSE, MMP2 and MMP9 activity are increased, where MMP9 activity is centered on meninges and parenchymal blood vessels in the brain in situ zymography (Sellner et al., 2006). In humans, high levels of MMP-9 were found in the cerebrospinal fluid (CSF) in viral meningitis (Kolb et al., 1998) and also in the serum of patients with viral meningoencephalitis (Beuche et al., 2000).
Additionally, high levels of MMP-2 and MMP-9 activity were observed within the CNS in the acute phase of HSV infection (manuscript under review) that persist for several months thereafter in experimental encephalitis (Martínez et al., 2004). The other probable mechanism of BBB disruption during HSV infection is via enhancement of several markers of AM such as ICAM-1, VCAM-1 and selectins on human dermal microvascular endothelial cells (Kim et al., 2000).

\subsection{Enhancing permeability via alterations in tight junc-} tions and increasing MMP expression

With the same BBB disruption mechanism as other viruses, human immunodeficiency virus (HIV) is one of the most studied neuroviruses in retrovirus family with respect to viral and host processes involved in encephalitis and BBB disruption. It causes severe neurological disorder known as HIV-associated neurocognitive disorder (HAND), leading to HIV-related encephalitis. In the early stages of HIV infection, the virus may enter CNS, infecting microglia and macrophages of the perivascular space and resulting in HIV encephalitis at the later stages of HIV infection (An et al., 1999; Gartner, 2000). The most common and pathogenic strain of HIV is HIV-1. It was found that BMEC dysfunction can be directly involved in the process of HIV-1 entry into the CNS (Wu et al., 2000). HIV-1 may lead to BBB disruption resulting in acquired immune deficiency syndrome (AIDS) neuropathogenesis (González-Scarano and Martín-Garcia 2005). The possible mechanism responsible for BBB disruption in HIV-1 encephalitis is alteration of TJ protein expression (Afonso et al., 2008; Gralinski et al., 2009; Strazza et al., 2011). A previous study revealed that primary human brain-derived microvascular or umbilical vein-derived endothelial cells infected with HIV-1 enabled the virus crossing the endothelial cell monolayers by altering TJ protein expression, enhancing permeability and matrix metalloproteinases (MMP2 and MMP9) expression (Eugenin et al., 2006). In addition, both transcellular and paracellular diapedesis of infected leukocytes is involved in HIV-1 transit across the BBB (Ivey et al., 2009). It is also hypothesized that HIV-1 trafficking into the brain may occur through a "Trojan horse" mechanism, where HIV infects CD4+ T-lymphocytes and circulating monocytes, leading to CNS entry through breaches in the $\mathrm{BBB}$, followed by the induction of inflammatory reactions that may play a critical role in HIV-1 entry into the brain (Liu et al., 2000). Additionally, high levels of soluble ICAM-1 were found in CSF of the patients suffering from HIV-associated neurological diseases (Heidenreich et al., 1994). It was also shown that HIV-infected monocytes/macrophages stimulate up-regulation of TNF-a, IL-6, VCAM-1, and E-selectin expression (Persidsky et al., 1997), resulting in neuronal injury and thus increasing the BBB permeability (de Vries et al., 1996; Abbott, 2000). Viral glycoprotein gp120 of HIV breaches the BBB through acti- 
Table 1. Neuroviruses and their entry mechanisms into CNS via BBB disruption

\begin{tabular}{|c|c|c|c|c|c|}
\hline No. & Family & Virus & Virus genome & Virus entry mechanisms & References \\
\hline \multirow[t]{3}{*}{1} & \multirow[t]{3}{*}{ Flaviviridae } & \multirow[t]{3}{*}{ JEV } & \multirow[t]{3}{*}{ Single-stranded RNA } & $\begin{array}{l}\text { Upregulation of ICAM-11 (CINC-1), and } \\
\text { RANTES activity. }\end{array}$ & Lai et al., 2012 \\
\hline & & & & $\begin{array}{l}\text { TJ alteration (Downregulation of clau- } \\
\text { din-1, claudin-5, and ZO-1 occludin. }\end{array}$ & Agrawal et al., 2013 \\
\hline & & & & $\begin{array}{l}\text { Induce microglial activation in the brain } \\
\text { leading to the expression of numer- } \\
\text { ous immune-related proteins such as } \\
\text { chemokines (MCP-1, MIP-1a, MIP-1b, } \\
\text { cytokines (IL-1, IL-6, IL-18, TNF-a). }\end{array}$ & Ghoshal et al., 2007 \\
\hline \multirow[t]{3}{*}{2} & \multirow[t]{3}{*}{ Flaviviridae } & \multirow[t]{3}{*}{ WNV } & \multirow{3}{*}{$\begin{array}{l}\text { Positive single-stranded } \\
\text { RNA }\end{array}$} & Trojan horse. & Wang et al., 2008b \\
\hline & & & & TJ proteins degradation. & $\begin{array}{l}\text { Wang et al., 2008a; Xu et al., } \\
2012\end{array}$ \\
\hline & & & & $\begin{array}{l}\text { High level of pro-inflammatory cytokines } \\
\text { and chemokines. }\end{array}$ & Kumar et al., 2010 \\
\hline 3 & Flaviviridae & ZIKV & $\begin{array}{l}\text { Positive single-stranded, } \\
\text { sense RNA }\end{array}$ & Trojan horse and TJs deformation. & $\begin{array}{l}\text { Dietrich, 2002; Wang et al., } \\
\text { 2008a; Li et al., } 2015\end{array}$ \\
\hline \multirow[t]{2}{*}{4} & \multirow[t]{2}{*}{ Paramyxoviridae } & \multirow[t]{2}{*}{$\mathrm{NiV}$} & \multirow[t]{2}{*}{$\begin{array}{l}\text { Negative single-stranded, } \\
\text { sense RNA }\end{array}$} & $\begin{array}{l}\text { High expression of IL- } 6 \text {, TNF-a, IL- } 1 \alpha \text {, } \\
\text { IL- } 1 \beta \text {, and IFN- } \alpha \text {. }\end{array}$ & $\begin{array}{l}\text { Bailey et al., 2006; Mathieu et } \\
\text { al., } 2011\end{array}$ \\
\hline & & & & $\begin{array}{l}\text { Increasing in the transendothelial } \\
\text { permeability. }\end{array}$ & Weingartl et al., 2005 \\
\hline \multirow[t]{2}{*}{5} & \multirow[t]{2}{*}{ Rhabdoviridae } & \multirow[t]{2}{*}{ RABV } & \multirow[t]{2}{*}{$\begin{array}{l}\text { Non-segmented negative } \\
\text { strand RNA }\end{array}$} & $\begin{array}{l}\text { Production of chemokines, cytokines, } \\
\text { and activation of immune cells. }\end{array}$ & Chai et al., 2015 \\
\hline & & & & Reducing the TJ protein. & Chai et al., 2015 \\
\hline \multirow[t]{2}{*}{6} & \multirow[t]{2}{*}{ Herpesviridae } & \multirow[t]{2}{*}{ HSV } & \multirow[t]{2}{*}{ Double-stranded DNA } & Degrading MMPs. & Lo et al., 2002 \\
\hline & & & & $\begin{array}{l}\text { Increasing several markers of AM such } \\
\text { as ICAM-1, VCAM-1. }\end{array}$ & Kim et al., 2000 \\
\hline \multirow[t]{3}{*}{7} & \multirow[t]{3}{*}{ Retroviridae } & \multirow[t]{3}{*}{ HIV } & \multirow{3}{*}{$\begin{array}{l}\text { Positive single-stranded, } \\
\text { sense RNA }\end{array}$} & Alterations of TJ protein expression. & Strazza et al., 2011 \\
\hline & & & & Trojan horse. & Liu et al., 2000 \\
\hline & & & & $\begin{array}{l}\text { Up-regulation of TNF- } \alpha \text {, IL-6, ICAM-1, } \\
\text { VCAM-1, and E-selectin expression. }\end{array}$ & $\begin{array}{l}\text { Heidenreich et al., 1994; de Vries } \\
\text { et al., 1996; Abbott, } 2000\end{array}$ \\
\hline
\end{tabular}

vating the $\mathrm{C}-\mathrm{X}-\mathrm{C}$ chemokine receptor type 4 (CXCR4) and chemokine receptors $\mathrm{C}-\mathrm{C}$ chemokine receptor type 5 (CCR5) (András et al., 2005; Kanmogne et al., 2005), leading to TJ protein degradation via proteasome (Nakamuta et al., 2008; Wang et al., 2011). Several mechanisms have been postulated to show how numerous neuroviruses enter the CNS via BBB disruption as shown in Table 1.

\section{Conclusion}

In conclusion, several mechanisms have been reviewed, showing how neuroviruses disrupt the BBB. Viruses such as JEV, WNV, HSV and HIV-1 disrupt the BBB by "Trojan horse" mechanism, in which the virus is carried into the brain by infected inflammatory cells via overexpression of $\mathrm{AM}$, or by altering the TJ proteins to enable penetration of inflammatory cells into the CNS as shown for viruses such as JEV, WNV, RABV and HIV-1. NiV on the other hand gains entry into the CNS through infection of glial cells in the brain parenchyma, thus allowing the virus to overcome the BBB. Viruses such as HSV and WNV also tend to cause BBB breakdown via activation of MMP2 and MMP9. However, the exact mechanism of entry of ZIKV is still speculative, and it may use similar mechanisms as other flaviviruses (e.g. JEV and RBV). In this reveiw, several mechanisms have been reviewed in order to understand the pathogenesis of neuroviruses and to develop effective therapeutic schemes of each virus in further investigations.

Acknowledgments. This study was supported by the University of Malaya under Grant UMRG-PR021C-13HTM.

\section{References}

Abbott NJ, Cell. Mol. Neurobiol. 20, 131-147, 2000. https://doi. org/10.1023/A:1007074420772

Abbott NJ, Patabendige AA, Dolman DE, Yusof SR, Begley DJ, Neurobiol. Dis. 37, 13-25, 2010. https://doi.org/10.1016/j. nbd.2009.07.030 
Abdullah S, Chang LY, Rahmat K, Goh KJ, Tan CT, Neurol. Asia 17, 71-74, 2012.

Afonso PV, Ozden S, Cumont MC, Seilhean D, Cartier L, Rezaie P, Mason S, Lambert S, Huerre M, Gessain A, PLoS Pathog, 4, e1000205, 2008. https://doi.org/10.1371/journal. ppat. 1000205

Agrawal T, Sharvani V, Nair D, Medigeshi GR, PloS One, 8, e69465, 2013. https://doi.org/10.1371/journal.pone.0069465

An SF, Groves M, Gray F, Scaravilli F, J. Neuropathol. Exp. Neurol. 58, 1156-1162, 1999. https://doi.org/10.1097/00005072199911000-00005

András IE, Pu H, Tian J, Deli MA, Nath A, Hennig B, Toborek M, J. Cereb. Blood Flow Metab. 25, 1159-1170, 2005. https:// doi.org/10.1038/sj.jcbfm.9600115

Argyris EG, Acheampong E, Wang F, Huang J, Chen K, Mukhtar M, Zhang H, Virology 367, 440-451, 2007. https://doi. org/10.1016/j.virol.2007.06.010

Armulik A, Genové G, Mäe M, Nisancioglu MH, Wallgard E, Niaudet C, He L, Norlin J, Lindblom P, Strittmatter K, Nature 468, 557-561, 2010. https://doi.org/10.1038/nature09522

Arsenio NML, Cerutti I, Farkas-Bargeton E, Acta neuropathol. 33, 245-256, 1975. https://doi.org/10.1007/BF00688397

Bailey SL, Carpentier PA, McMahon EJ, Begolka WS, Miller SD, Crit. Rev. Immunol. 26, 149-188, 2006. https://doi. org/10.1615/CritRevImmunol.v26.i2.40

Banati RB, Gehrmann J, Schubert P, Kreutzberg GW, Glia 7, 111118, 1993. https://doi.org/10.1002/glia.440070117

Bayer A, Lennemann NJ, Ouyang Y, Bramley JC, Morosky S, Marques ETDA, Cherry S, Sadovsky Y, Coyne CB, Cell Host Microbe 19, 705-712, 2016. https://doi.org/10.1016/j. chom.2016.03.008

Bell T, Field E, Narang H, Arch. Gesamte Virusforsch. 35, 183-193, 1971. https://doi.org/10.1007/BF01249709

Beuche W, Yushchenko M, Mäder M, Maliszewska M, Felgenhauer K, Weber F, Neuroreport 11, 3419-3422, 2000. https://doi. org/10.1097/00001756-200011090-00003

Bonaparte MI, Dimitrov AS, Bossart KN, Crameri G, Mungall BA, Bishop KA, Choudhry V, Dimitrov DS, Wang LF, Eaton BT, Proc. Natl. Acad. Sci. USA 102, 10652-10657, 2005. https://doi.org/10.1073/pnas.0504887102

Brasil P, Pereira J, Jose P, Raja Gabaglia C, Damasceno L, Wakimoto M, Ribeiro Nogueira RM, Carvalho de Sequeira P, Machado Siqueira A, Abreu de Carvalho LM, Cotrim da Cunha D, Zika N. Engl. J. Med. 375, 2321-2334, 2016. https://doi.org/10.1056/NEJMoa1602412

Casrouge A, Zhang SY, Eidenschenk C, Jouanguy E, Puel A, Yang K, Alcais A, Picard C, Mahfoufi N, Nicolas N, Science 314, 308-312, 2006. https://doi.org/10.1126/science.1128346

Ceccaldi P. Gillet, J, Tsiang H, J. Neuropathol. Exp. Neurol. 48, 620-630, 1989. https://doi.org/10.1097/00005072198911000-00004

Chai Q, He WQ, Zhou M, Lu H, Fu ZF, J. Virol. 88, 4698-4710, 2004. https://doi.org/10.1128/JVI.03149-13

Chai Q, She R, Huang Y, Fu ZF, J. Virol. 89, 870-876, 2015. https:// doi.org/10.1128/JVI.02154-14

Charlton K, Rabies, Springer, pp. 101-150, 1988. https://doi. org/10.1007/978-1-4613-1755-5 5
Chen ST, Liu RS, Wu MF, Lin YL, Chen SY, Tan DTW, Chou TY, Tsai IS, Li L, Hsieh SL, PLoS Pathog. 8, e1002655, 2012. https://doi.org/10.1371/journal.ppat.1002655

Chua K, Bellini W, Rota P, Harcourt B, Tamin A, Lam S, Ksiazek T, Rollin P, Zaki S, Shieh WJ, Science, 288, 1432-1435, 2000. https://doi.org/10.1126/science.288.5470.1432

Citi S, Sabanay H, Jakes R, Geiger B, Kendrick-Jones J, Nature, 333, 272-276, 1988. https://doi.org/10.1038/333272a0

Citi S, Sabanay H, Kendrick-Jones J, Geiger B, J. Cell Sci. 93, 107 $122,1989$.

Daffis S, Samuel MA, Suthar MS, Gale M, Diamond MS, J. Virology, 82, 10349-10358, 2008. https://doi.org/10.1128/ JVI.00935-08

Dang J, Tiwari SK, Lichinchi G, Qin Y, Patil VS, Eroshkin AM, Rana TM, Cell Stem Cell 19, 258-265, 2016. https://doi. org/10.1016/j.stem.2016.04.014

de Vries HE, Blom-Roosemalen MC, van Oosten M, de Boer AG, van Berkel TJ, Breimer DD, Kuiper J, J. Neuroimmunol. 64, 37-43, 1996. https://doi.org/10.1016/0165-5728(95)00148-4

De Wit E, Bushmaker T, Scott D, Feldmann H, Munster VJ, PLoS Negl. Trop. Dis. 5, e1432, 2011. https://doi.org/10.1371/ journal.pntd.0001432

Diagana M, Preux PM, Dumas M, J. Neurol. Sci. 262, 165-170, 2007. https://doi.org/10.1016/j.jns.2007.06.041

Dick G, Trans. R. Soc. Trop. Med. Hyg. 46, 521-534, 1952. https:// doi.org/10.1016/0035-9203(52)90043-6

Dietrich JB, J. Neuroimmunol. 128, 58-68, 2002. https://doi. org/10.1016/S0165-5728(02)00114-5

Dore DP, Curr. Pharm. Des. 14, 1581-1593, 2008. https://doi. org/10.2174/138161208784705469

Durbin JE, Hackenmiller R, Simon MC, Levy DE, Cell 84, 443-450, 1996. https://doi.org/10.1016/S0092-8674(00)81289-1

Eugenin EA, Osiecki K, Lopez L, Goldstein H, Calderon TM, Berman JW, J. Neurosci. 26, 1098-1106, 2006. https://doi. org/10.1523/JNEUROSCI.3863-05.2006

Farkas BE, Diebler M, Kristensson K, Lycke E, Sourander P, Acta Neuropathol. 33, 51-57, 1975. https://doi.org/10.1007/ BF00685964

Faul EJ, Wanjalla CN, Suthar MS, Gale Jr M, Wirblich C, Schnell MJ, PLoS Pathog. 6, e1001016, 2010. https://doi.org/10.1371/ journal.ppat.1001016

Fields B, Knipe D, Howley P, Fields virology. 5th. Philadelphia: Wolters Kluwer Health/Lippincott Williams \& Wilkins, 2007.

Fitzgerald KA, McWhirter SM, Faia KL, Rowe DC, Latz E, Golenbock DT, Coyle AJ, Liao SM, Maniatis T, Nat. Immunol. 4, 491-496, 2003. https://doi.org/10.1038/ni921

Fletcher NF, Meeker RB, Hudson LC, Callanan JJ, Vet. J. 188, 260269, 2011. https://doi.org/10.1016/j.tvjl.2010.03.022

Fontana JM, Bankamp B, Rota PA, Immunol. Rev. 225, 46-67 2008. https://doi.org/10.1111/j.1600-065X.2008.00669.x

Fredericksen BL, Keller BC, Fornek J, Katze MG, Gale M, J. Virol. 82, 609-616, 2008. https://doi.org/10.1128/JVI.01305-07

Furuse M, Fujita K, Hiiragi T, Fujimoto K, Tsukita S, J. Cell Biol. 141, 1539-1550, 1998. https://doi.org/10.1083/ jcb.141.7.1539 
Furuse M, Hirase T, Itoh M, Nagafuchi A, Yonemura S, Tsukita S, J. Cell Biol. 123, 1777-1788, 1993. https://doi.org/10.1083/ jcb.123.6.1777

Gartner S, Science, 287, 602-604, 2000. https://doi.org/10.1126/ science.287.5453.602

Gaudin Y, Ruigrok RW, Tuffereau C, Knossow M, Flamand A, Virology, 187, 627-632, 1992. https://doi.org/10.1016/00426822(92)90465-2

German AC, Myint KSA, Mai NTH, Pomeroy I, Phu NH, Tzartos J, Winter P, Collett J, Farrar J, Barrett A, Trans. R. Soc. Trop. Med. Hyg. 100, 1135-1145, 2006. https://doi. org/10.1016/j.trstmh.2006.02.008

Ghoshal A, Das S, Ghosh S, Mishra MK, Sharma V, Koli P, Sen E, Basu A, Glia 55, 483-496, 2007. https://doi.org/10.1002/ glia.20474

González-Scarano F, Martín-Garcia J, Nat. Rev. Immunol. 5, 69$81,2005$.

Goodbourn S, Randall RE, J. Interferon Cytokine Res. 29, 539-548, 2009. https://doi.org/10.1089/jir.2009.0071

Gralinski LE, Ashley SL, Dixon SD, Spindler KR, J. Virol. 83, 93989410, 2009. https://doi.org/10.1128/JVI.00954-09

Gumbiner B, Lowenkopf T, Apatira D, Proc. Natl. Acad. Sci. USA 88, 3460-3464, 1991. https://doi.org/10.1073/ pnas.88.8.3460

Gupta N, Rao PL, Virol. J. 8, 1, 2011. https://doi.org/10.1186/1743422X-8-92

Hamel R, Dejarnac O, Wichit S, Ekchariyawat P, Neyret A, Luplertlop N, Perera-Lecoin M, Surasombatpattana P, Talignani L, Thomas F, J. Virol. 89, 8880-8896, 2015. https://doi. org/10.1128/JVI.00354-15

Hauwel M, Furon E, Canova C, Griffiths M, Neal J, Gasque P, Brain Res. Rev. 48, 220-233, 2005. https://doi.org/10.1016/j. brainresrev.2004.12.012

Heidenreich F, Arendt G, Jander S, Jablonowski H, Stoll G, J. Neuroimmunol. 52, 117-126, 1994. https://doi. org/10.1016/0165-5728(94)90105-8

Hudson SJ, Dix RD, Streilein JW, J. Infect. Dis. 163, 720-727, 1991. https://doi.org/10.1093/infdis/163.4.720

Ishikawa H, Ma Z, Barber GN, Nature, 461, 788-792, 2009. https:// doi.org/10.1038/nature08476

Ivey NS, MacLean AG, Lackner AA, J. Neurovirol. 15, 111-122, 2009. https://doi.org/10.1080/13550280902769764

Jackson AC, Randle E, Lawrance G, Rossiter JP, J. Neurovirol. 14, 368375, 2008. https://doi.org/10.1080/13550280802216502

Jamieson GA, Maitland NJ, Wilcock GK, Craske J, Itzhaki RF, J. Med. Virol. 33, 224-227, 1991. https://doi.org/10.1002/ jmv.1890330403

Johnson RT, Olson LC, Buescher EL, Arch. Neurol. 18, 260-264, 1968. https://doi.org/10.1001/archneur.1968.00470330050004

Kacem K, Lacombe P, Seylaz J, Bonvento G, Glia 23, 1-10, 1998. https://doi.org/10.1002/(SICI)1098-1136(199805)23:1<1::AID-GLIA1>3.0.CO;2-B

Kanmogne, GD, Primeaux C, Grammas P, J. Neuropathol. Exp. Neurol. 64, 498-505, 2005. https://doi.org/10.1093/ jnen $/ 64.6 .498$

Kim YC, Bang D, Lee S, Lee KH, J. Dermatol. Sci. 24, 38-47, 2000. https://doi.org/10.1016/S0923-1811(00)00080-3
Kobayashi H, Boelte KC, Lin PC, Curr. Med. Chem. 14, 377-386, 2007. https://doi.org/10.2174/092986707779941032

Kolb SA, Lahrtz F, Paul R, Leppert D, Nadal D, Pfister HW, Fontana A, J. Neuroimmunol. 84, 143-150, 1998. https://doi. org/10.1016/S0165-5728(97)00247-6

Koyuncu OO, Hogue IB, Enquist LW, Cell Host Microbe, 13, 379393, 2013. https://doi.org/10.1016/j.chom.2013.03.010

Kuang Y, Lackay SN, Zhao L, Fu ZF, Virus Res. 144, 18-26, 2009. https://doi.org/10.1016/j.virusres.2009.03.014

Kumar M, Verma S, Nerurkar VR, J. Neuroinflammation 7, 73, 2010. https://doi.org/10.1186/1742-2094-7-73

Lai CY, Ou YC, Chang CY, Pan HC, Chang CJ, Liao SL, Su HL, Chen CJ, J. Neurochem. 123, 250-261, 2012. https://doi. org/10.1111/j.1471-4159.2012.07889.x

Lander HM, Grant AM, Albrecht T, Hill T, Peters CJ, Endothelial Cell Permeability and Adherens Junction Disruption Induced by Junín Virus Infection. Am. J. Trop. Med. Hyg. 90, 993-1002, 2014. https://doi.org/10.4269/ajtmh.13-0382

Lazear HM, Govero J, Smith AM, Platt DJ, Fernandez E, Miner JJ, Diamond MS, Cell Host Microbe 19, 720-730, 2016. https://doi.org/10.1016/j.chom.2016.03.010

Lazear HM, Pinto AK, Vogt MR, Gale M, Diamond MS, J. Virol. 85, 7186-7194, 2011. https://doi.org/10.1128/JVI.00396-11

Lee B, Ann. N. Y. Acad. Sci. 1102, 51-65, 2007. https://doi. org/10.1196/annals.1408.004

Lehner C, Gehwolf R, Tempfer H, Krizbai I, Hennig B, Bauer HC, Bauer H, Antioxid. Redox Signal. 15, 1305-1323, 2011. https://doi.org/10.1089/ars.2011.3923

Lentz TL, Burrage TG, Smith AL, Crick J, Tignor GH, Science 215, 182-184, 1982. https://doi.org/10.1126/science.7053569

Li F, Wang Y, Yu L, Cao S, Wang K., Yuan J, Wang C, Wang K Cui M, Fu ZF, J. Virol. 89, 5602-5614, 2015. https://doi. org/10.1128/JVI.00143-15

Li XD, Wu J, Gao D, Wang H, Sun L, Chen Z, Science 341, 13901394, 2013. https://doi.org/10.1126/science. 1244040

Lim PY, Behr MJ, Chadwick CM, Shi PY, Bernard KA, J. Virol. 85, 5197-5201, 2011. https://doi.org/10.1128/JVI.02692-10

Liu Y, Tang XP, McArthur JC, Scott J, Gartner S, J. Neurovirol. 6, S70-S81, 2000.

Lo EH, Wang X, Cuzner ML, J. Neurosci. Res. 69, 1-9, 2000. https:// doi.org/10.1002/jnr.10270

Lopez RMA, Fischer R, Torres-Badillo CC, Davies HA, Logan K, Pfizenmaier K, Male DK, Sharrack B, Romero IA, J. Immunol. 189, 3130-3139, 2012. https://doi.org/10.4049/ jimmunol.1103460

Luby SP, Gurley ES, Epidemiology of henipavirus disease in humans Henipavirus. Springer, pp. 25-40, 2012.

Luissint AC, Artus C, Glacial F, Ganeshamoorthy K, Couraud PO, Fluids Barriers CNS, 9, 1-12, 2012. https://doi. org/10.1186/2045-8118-9-23

Maisner A, Neufeld J, Weingartl H, Thromb. Haemost. 102, 10141023, 2009.

Marcovistz R, Germano PML, Rivière Y, Tsiang H, Hovanessian AG, J. Interferon Res. 7, 17-27, 1987. https://doi.org/10.1089/ jir.1987.7.17

Mariano C, Sasaki H, Brites D, Brito MA, Eur. J. Cell Biol. 90, 787796, 2011. https://doi.org/10.1016/j.ejcb.2011.06.005 
Martìn P, Inés Lostaglio S, Schneemann M, Williams L, Romano M, Fruscella P, Panzeri C, Stoppacciaro A, Ruco L, Villa A, J. Cell Biol. 142, 117-127, 1998. https://doi.org/10.1083/ jcb.142.1.117

Martines RB, MMWR. Morbidity and mortality weekly report, 65, 2016.

Martínez T, Francisco J, Wagner S, Haas J, Kehm R, Sellner J, Hacke W, Meyding-Lamadé U, Neurosci. Lett. 368, 274-278, 2004. https://doi.org/10.1016/j.neulet.2004.06.064

Mathieu C, Pohl C, Szecsi J, Trajkovic-Bodennec S, Devergnas S, Raoul H, Cosset FL, Gerlier D, Wild TF, Horvat B, J. Virol. 85, 7863-7871, 2011. https://doi.org/10.1128/ JVI.00549-11

McGavern DB, Kang SS, Nat. Rev. Immunol. 11, 318-329, 2011. https://doi.org/10.1038/nri2971

Meaney-Delman D, MMWR. Morbidity and mortality weekly report, 65, 2016.

Miner JJ, Cao B, Govero J, Smith AM, Fernandez E, Cabrera OH, Garber C, Noll M, Klein RS, Noguchi KK, Cell 165, 10811091 2016. https://doi.org/10.1016/j.cell.2016.05.008

Mishra MK, Dutta K, Saheb SK, Basu A, Neurochem. Int. 55, 717-723, 2009. https://doi.org/10.1016/j. neuint.2009.07.006

Mlakar J, Korva M, Tul N, Popović M, Poljšak-Prijatelj M, Mraz J, Kolenc M, Resman Rus K, Vesnaver Vipotnik T, Fabjan Vodušek V, Zika virus associated with microcephaly. N. Engl. J. Med. 374, 951-958, 2016. https://doi.org/10.1056/ NEJMoa1600651

Morita K, Sasaki H, Furuse M, Tsukita S, J. Cell Biol. 147, 185-194, 1999. https://doi.org/10.1083/jcb.147.1.185

Munste, V J, Prescott JB, Bushmaker T, Long D, Rosenke R, Thomas T, Scott D, Fischer ER, Sci. Rep. 2, 736, 2012. https://doi. org/10.1038/srep00736

Nair S, Diamond MS, Curr. Opin. Immunol. 36, 47-53, 2015.https:// doi.org/10.1016/j.coi.2015.06.011

Nakamuta S, Endo H, Higashi Y, Kousaka A, Yamada H, Yano M, Kido H, J. Neurovirol. 14, 186-195, 2008. https://doi. org/10.1080/13550280801993630

Nayak S, Lei J, Pekosz A, Klein S, Burd I, Pathogenesis and molecular mechanisms of Zika Virus. Vol. 34, Seminars in Reproductive Medicine. Thieme Medical Publishers, City. pp. 266-272, 2016.

Negrete OA, Levroney EL, Aguilar HC, Bertolotti-Ciarlet A, Nazarian R, Tajyar S, Lee B, Nature 436, 401-405, 2005. https:// doi.org/10.1038/nature 03838

Negrete OA, Wolf MC, Aguilar HC, Enterlein S, Wang W, Mühlberger E, Su SV, Bertolotti-Ciarlet A, Flick R, Lee B, PLoS Pathog. 2, e7, 2006. https://doi.org/10.1371/journal. ppat.0020007

Nowakowski TJ, Pollen AA, Di Lullo E, Sandoval-Espinosa C, Bershteyn M, Kriegstein AR, Cell stem cell, 18, 591-596, 2016. https://doi.org/10.1016/j.stem.2016.03.012

Ohnishi H, Nakahara T, Furuse K, Sasaki H, Tsukita S, Furuse M, J. Biol. Chem. 279, 46014-46022, 2004. https://doi. org/10.1074/jbc.M402616200

Ohtsuki S, Yamaguchi H, Katsukura Y, Asashima T, Terasaki T, J. Neurochem. 104, 147-154, 2008.
Pekny M, Stanness KA, Eliasson C, Betsholtz C, Janigro D, Glia 22, 390-400, 1998. https://doi.org/10.1002/(SICI)1098-1136(199804)22:4<390::AID-GLIA8>3.0.CO;2-7

Persidsky Y, Buttini M, Limoges J, Bock P, Gendelman HE, J. Neurovirol. 3, 401-416, 1997. https://doi.org/10.3109/ $\underline{13550289709031186}$

Phares TW, Kean RB, Mikheeva T, Hooper DC, J. Immunol. 176, 7666-7675, 2006. https://doi.org/10.4049/ jimmunol.176.12.7666

Poli G, Orenstein JM, Kinter A, Folks TM, Fauci AS, Science 244, 575, 1989. https://doi.org/10.1126/science. 2470148

Poliakov A, Cotrina M, Wilkinson DG, Dev. Cell 7, 465-480, 2004. https://doi.org/10.1016/j.devcel.2004.09.006

Raschilas F, Wolff M, Delatour F, Chaffaut C, De Broucker T, Chevret S, Lebon P, Canton P, Rozenberg F, Clin. Infect. Dis. 35, 254-260, 2002. https://doi. org/10.1086/341405

Retallack H, Di Lullo E, Arias C, Knopp KA, Sandoval-Espinosa C, Laurie MT, Zhou Y, Gormley M, Leon WRM, Krencik R, BioRxiv, 058883, 2016.

Rossi SL, Tesh RB, Azar SR, Muruato AE, Hanley KA, Auguste AJ, Langsjoen RM., Paessler S, Vasilakis N, Weaver SC, Am. J. Trop. Med. Hyg. 94, 1362-1369, 2016. https://doi. org/10.4269/ajtmh.16-0111

Savarin C, Bergmann CC, Curr. Opin. Pharmacol. 8, 472-479, 2008. https://doi.org/10.1016/j.coph.2008.05.002

Schlitt M, Lakeman AD, Wilson ER, To A, Acoff RW, Harsh GR, Whitley RJ, J. Infect. Dis. 153, 732-735, 1986. https://doi. org/10.1093/infdis/153.4.732

Schnell MJ, McGettigan JP, Wirblich C, Papaneri A, Nat. Rev. Microbiol. 8, 51-61, 2010. https://doi.org/10.1038/nr$\underline{\text { micro2260 }}$

Sejvar JJ, Hossain J, Saha SK, Gurley ES, Banu S, Hamadani JD, Faiz MA, Siddiqui F, Mohammad QD, Mollah AH, Ann. Neurol. 62, 235-242, 2007. https://doi.org/10.1002/ ana. 21178

Sellner J, Dvorak F, Zhou Y, Haas J, Kehm R, Wildemann B, Meyding-Lamadè U, Neurosci. Lett. 374, 197-202, 2005. https://doi.org/10.1016/j.neulet.2004.10.054

Sellner J, Simon F, Meyding-Lamade U, Leib SL, Brain res. 1125, 155-162, 2006. https://doi.org/10.1016/j. brainres.2006.09.093

Shima D, Adamis A, Ferrara N, Yeo K, Yeo T, Allende R, Folkman J, D'amore P, Mol. Med. 1, 182, 1995.

Shirato K, Miyoshi H, Goto A, Ako Y, Ueki T, Kariwa H, Takashima I, J. Gen. Virol. 85, 3637-3645, 2004. https://doi. org/10.1099/vir.0.80247-0

Sørensen LN, Reinert LS, Malmgaard L, Bartholdy C, Thomsen AR, Paludan SR, J. Immunol. 181, 8604-8612, 2008. https:// doi.org/10.4049/jimmunol.181.12.8604

Sorgeloos F, Kreit M, Hermant P, Lardinois C, Michiels T, Viruses, 5, 834-857, 2013. https://doi.org/10.3390/v5030834

Stanimirovic D, Satoh K, Brain Pathol. 10, 113-126, 2003. https:// doi.org/10.1111/j.1750-3639.2000.tb00248.x

Stevenson BR, Siliciano JD, Mooseke, MS, Goodenough DA, J. Cell Biol. 103, 755-766, 1986. https://doi.org/10.1083/ jcb.103.3.755 
Strazza M, Pirrone V, Wigdahl B, Nonnemacher MR, Brain Res. 1399, 96-115, 2011. https://doi.org/10.1016/j. brainres.2011.05.015

Suthar MS, Brassil MM, Blahnik G, McMillan A, Ramos HJ, Proll SC, Belisle SE, Katze MG, Gale Jr M, PLoS Pathog. 9, e1003168, 2013. https://doi.org/10.1371/journal. ppat. 1003168

Szretter KJ, Daffis S, Patel J, Suthar MS, Klein RS, Gale M, Diamond MS, J. Virol. 84, 12125-12138, 2010. https://doi. org/10.1128/JVI.01026-10

Thoulouze MI, Lafage M, Schachner M, Hartmann U, Cremer H, Lafon M, J. Virol. 72, 7181-7190, 1998.

Town T, Bai F, Wang T, Kaplan AT, Qian F, Montgomery RR, Anderson JF, Flavell RA, Fikrig E, Immunity 30, 242-253, 2009. https://doi.org/10.1016/j.immuni.2008.11.012

Tuffereau C, Bénéjean J, Blondel D, Kieffer B, Flamand A, EMBO J. 17, 7250-7259, 1998. https://doi.org/10.1093/ emboj/17.24.7250

Tyler KL, Arch. Neurol. 66, 939-948, 2009.

Ubogu EE, Callahan MK, Tucky BH, Ransohoff RM, J. Neuroimmunol. 179, 132-144, 2006. https://doi.org/10.1016/j. jneuroim.2006.06.004

Verma S, Kumar M, Gurjav U, Lum S, Nerurkar VR, Virology, 397, 130-138, 2010. https://doi.org/10.1016/j. virol.2009.10.036

Verma S, Lo Y, Chapagain M, Lum S, Kumar M, Gurjav U, Luo H, Nakatsuka A, Nerurkar VR, Virology, 385, 425-433, 2009. https://doi.org/10.1016/j.virol.2008.11.047

Wang LZ, Yu JT, Miao D, Wu ZC, Zong Y, Wen CQ, Tan L, Brain Res. 1381, 202-207, 2011. https://doi.org/10.1016/j. brainres.2011.01.007

Wang P, Dai J, Bai F, Kong KF, Wong SJ, Montgomery RR, Madri JA, Fikrig E, J. Virol. 82, 8978-8985, 2008a. https://doi. org/10.1128/JVI.00314-08

Wang S, Welte T, McGargill M, Town T, Thompson J, Anderson JF, Flavel, RA, Fikrig E, Hedrick SM,Wang T, J. Im- munol. 181, 2084-2091, 2008b. https://doi.org/10.4049/ jimmunol.181.3.2084

Wang T, Town T, Alexopoulou L, Anderson JF, Fikrig E, Flavell RA, Nat. Med. 10, 1366-1373, 2004. https://doi.org/10.1038/ $\underline{\mathrm{nm} 1140}$

Weingartl H, Czub S, Copps J, Berhane Y, Middleton D, Marszal P, Gren J, Smith G, Ganske S, Manning L, J. Virol. 79, 7528-7534, 2005. https://doi.org/10.1128/JVI.79.12.7528-7534.2005

Welte T, Reagan K, Fang H, Machain-Williams C, Zheng X, Mendell N, Chang GJJ, Wu P, Blair CD, Wang T, J. Gen. Virol. 90, 2660-2668, 2009. https://doi.org/10.1099/vir.0.011783-0

Wiktor TJ, György E, Schlumberger HD, Sokol F, Koprowski H, J. Immunol. 110, 269-276, 1973.

Wilhelm I, Fazakas C, Krizbai IA, Acta Neurobiol. Exp. (Wars), 71, 113-128, 2011.

Wong KT, Shieh WJ, Kumar S, Norain K, Abdullah W, Guarner J, Goldsmith CS, Chua KB, Lam SK, Tan CT, Am. J. Pathol. 161, 2153-2167, 2002. https://doi.org/10.1016/S00029440(10)64493-8

Wu DT, Woodman SE, Weiss JM, McManus CM, D'Aversa TG, Hesselgesser J, Major EO, Nath A, Berman JW, J. Neurovirol. 6, S82-S85, 2000.

Xu, M, Lee EM, Wen Z, Cheng Y, Huang WK, Qian X, Tcw J, Kouznetsova J, Ogden SC, Hammack C et al., Nat. Med. 22, 1101-1107, 2016. https://doi.org/10.1038/nm.4184

Xu Z, Waeckerlin R, Urbanowski MD, Van Marle G, Hobman TC, PloS One 7, e37886, 2012. https://doi.org/10.1371/ journal.pone.0037886

Yang Y, Ye J, Yang X, Jiang R, Chen H, Cao S, Virol. J. 8, 1, 2011. https://doi.org/10.1186/1743-422X-8-1

Zhang RL, Chopp M, Zaloga C, Zhang ZG, Jiang N, Gautam SC, Tang WX, Tsang W, Anderson DC, Manning AM, Brain Res. 682, 182-188, 1995. https://doi.org/10.1016/00068993(95)00346-R

Zhao L, Toriumi H, Kuang Y, Chen H, Fu ZF, J. Virol. 83, 1180811818, 2009. https://doi.org/10.1128/JVI.01346-09 